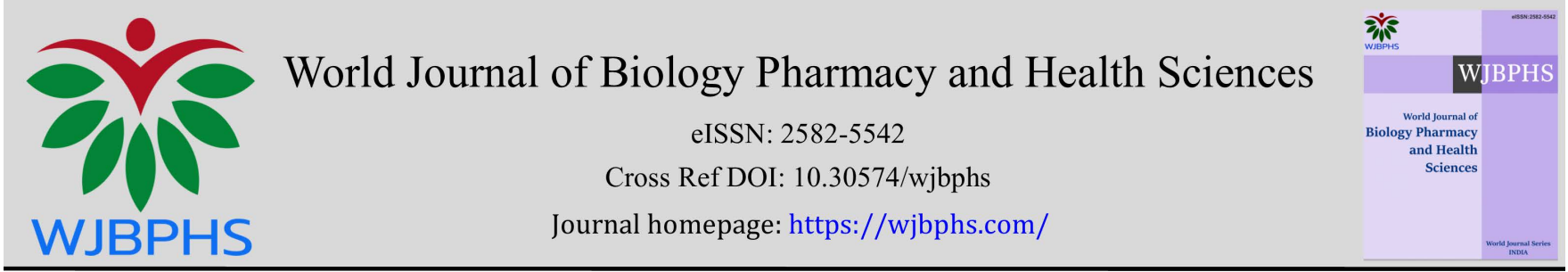

(RESEARCH ARTiCLE)

\title{
Screening of wound healing effect of Elaeis guineensis Oil, extract of Vernonia amygdalina mixed with dried egg albumin on burn wound inflicted guinea pig
}

\author{
Osuala Felix N *, Ezechukwu Laeticia Amarachukwu and Tony Panama Ogheneochuko \\ Department of Pharmacognosy Madonna University Nigeria, Elele Campus Rivers State, Nigeria.
}

World Journal of Biology Pharmacy and Health Sciences, 2021, 08(01), 013-028

Publication history: Received on 10August; revised on 24 September 2021; accepted on 26 September 2021

Article DOI: https://doi.org/10.30574/wjbphs.2021.8.1.0098

\begin{abstract}
Combined action of Vernonia amygdalinaone of the herbs belonging to the family Asteraceae and other pharmacognostic raw materials has been used in traditional medicine for ages. It produces quick therapeutic results in the treatment of various conditions and diseases such as malaria, diabetes, inflammation, hypertension to mention but few.
\end{abstract}

Aim: This work is the"screening of wound healing effect of Elaeis guineensis oil, extract of vernonia amygdalina, mixed with egg albumin on burn wound inflicted guinea pig".

Method: Five male guinea pigs were used for the study. Burn injury was inflicted on the anaesthetized guinea pigs using hot metallic knife. The extract at different doses (low, medium and high conc.) was applied on the injury for subject A $C$ respectively, subject D (Negative control) was cleaned with only Normal saline and Dermazin cream (Positive control) was applied on the injury for subject $\mathrm{E}$.

Result: The measurement of wound contraction and epithelialization were observed and results were recorded after 7days, 14days and 21days respectively. There was initial increase in burn wound surface area in the guinea pig used as negative control before the wound contraction and epithelilization reduced a bit. There was rapid reduction in the wound size of the guinea pig treated with the medium concentration of the extract and the dermazin cream (positive control), although the dermazin healed neatly, the medium concentration of the extract healed faster. The results obtained encourage the use of the mixture of $v$. amygdalina, palmoil and egg albumin in wound healing.

Keywords: Vernonia amygdalina; Elaeis guineensis oil; Wound healing; Egg albumen

\section{Introduction}

There has been a great deal of interest recently in the role of complementary and alternative medicines for the treatment of various acute and chronic diseases.

Herbal medicine includes herbs, herbal materials, herbal preparation and finished herbal products that contain active ingredients of plants' parts, or other plant materials or combinations (Saad et al., 2011) [1]. Herbal medicine has been used to treat, alleviate virtually every possible medical condition. Herbs can be administered in many forms, the most common of which is in the form of a liquid that is drunk by the patient-either an herbal tea or a [possibly diluted] plant extract (Saad et al., 2011) [1].

\footnotetext{
${ }^{*}$ Corresponding author: Osuala Felix N

Department of Pharmacognosy Madonna University Nigeria, Elele Campus Rivers State, Nigeria.

Copyright ( 12021 Author(s) retain the copyright of this article. This article is published under the terms of the Creative Commons Attribution Liscense 4.0
} 
Standardization of herbal drugs became very necessary for establishment of doses and drug forms. The ratio of raw materials to solvent. Different specimens of even the same plant may vary in chemical contents. For this reason, thin layer chromatography is sometimes used by growers to assess the content of their products before use. Most topical applications are oil extractions of herbs. Taking a food grade oil and soaking herbs in it for weeks to months would allow certain phytochemicals to be extracted into the oil. This oil can then be made into salves, creams, lotions, or simply used as an oil for topical application. Many massage oils, antibacterial salves and woundhealing compounds are made this way (Odinsson et al., 2010) [2].

Herbal medicines have the following advantages:

- More affordable than conventional medicine

- Easier to obtain than prescription medicine

- Stabilizes hormones and metabolism

- Gives natural healing

- $\quad$ Strengthens immune system

- Has fewer side effects.

Herb scould cause adverse effects. (Talalay 2001) [3] Futhermore," adulteration, wrong formulation, or deficiency in the understanding of plant and drug interactions have led to adverse reactions that could be life threatening sometimes" (Elvis-Lewis M, 2001)[4].

\section{Morphology of Vernonia amygdalina}

Vernonia amygdalina is a shrub or small tree of 2-5 $\mathrm{m}$ with petiolate leaf of about $6 \mathrm{~cm}$ diameter and elliptic shape. The name asteracea is derived from the type genus aster while compositae which is an older but still valid name means composite and refers to the characteristic inflorescence, a special type of pseudanthium found in only a few other angiosperm families.

It is commonly known as bitterleaf in places where it is grown.

\subsection{Local names}

- Igbo -Onugbu

- Edo - Agba

- Yoruba - Ewuro

- Tiv - Hyuna

- $\quad$ Cross rivers - Etidot Hausa - Chusardoki

V.amygdalina grows under a range of ecological zonesin Africa and produces large mass of forage and is drought tolerant. There are about 200 species of Vernonia.

\subsection{Plant taxonomy}

Classification:

Plantae (kingdom)

Angiosperm (phylum)

Dicotyledons(class)

Archichylamdae (sub class)

Campanulales (order)

Asteracea (family)

Tubifloral (sub family)

Vernonieae (Genus)

Amygdalina(species) 


\subsection{Ethnomedicinal uses}

V.amygdalina is effective against amoebic dysentery, gastrointestinal disorders,antimicrobial, antimalaria, antiparasitic, antidiabetic, anti-inflammatory, anticancer and antioxidant effect.

The antioxidant effect of $V$. amygdalina can be used for the enhancement of immune system through many cytokines (including NF KB, pro-inflammatory molecules) regulation.(Izerbigie et al., 2004) [5].

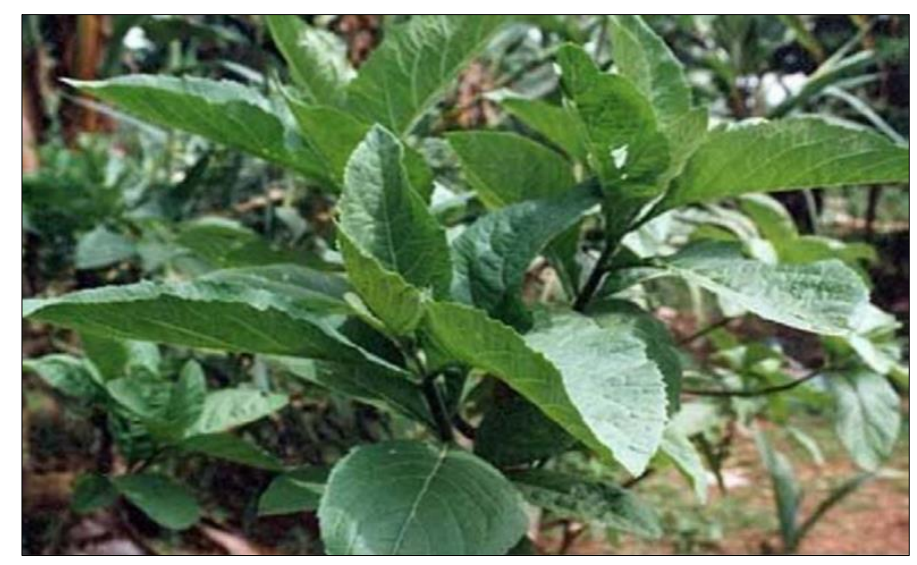

Figure 1 The plant Vernonia amygdalina

\subsection{OIL PALM (Elaeis guinensis)}

The species of oil palm includes those that are native to Africa (Elaeis guineensis) and those native to south and Central America (Elaeis oleifera). Both species belongs to Arecaceae family and are perennial tropical plants. Oil palm trees are usually not branched and has a long stout single stem, or trunk, terminating in a crown of 7-100 leaves. Oil palm leaves are pinnate reaching 3-5 $\mathrm{m}$ (9.8-16.4 ft) in length. The fruits are large and red in colour and are usually in bunches. A bunch may produce up to 200 fruits and the oil is extracted from the mesocarp of the fruit and kernel. Oil palm trees can reach heights of 20-30 m (65.6-98.4 ft) and has a life span of over 45-60 years.

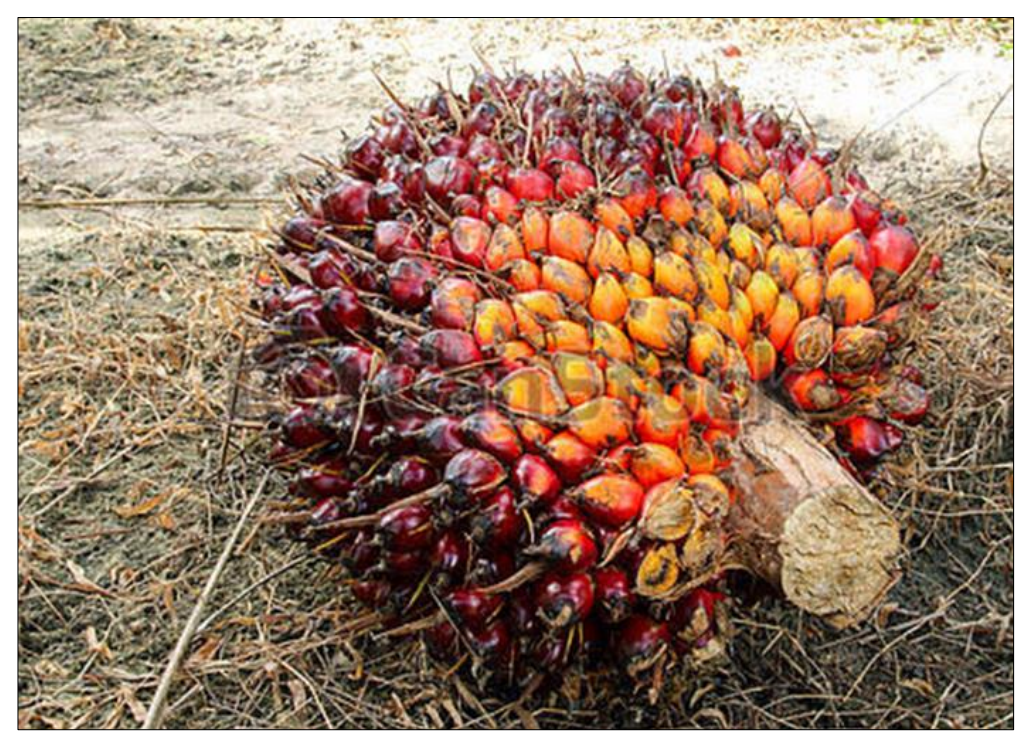

Figure 2 Bunch of oil palm fruits

Vitamin found in palm oil has been said to accelerate wound healing. Fresh palm oil is the most common antidote for injested poison among indigenous people of south-south Nigeria. It is effective only before the poison is absorbed into systemic circulation. Palm oil is the most popular cooking ingredient in this area. Hence, it becomes the first aid in case of poisoning. Children are forced to drink large quantity of the oil to either regurgitate the poison or neutralize its effect. 
There is also the application of oil to skin to reduce skin itches. Sometimes the oil is applied alone, other times it is mixed with some herbs other materials to form what is called herbal medicine.

\subsection{Egg white (albumen)}

Egg white is the clear liquid also called the albumen or the glair contained within an egg. I Egg white consists primarily of about $90 \%$ water into which about $10 \%$ proteins (including albumins, mucoproteins and globulins) are dissolved. Unlike the yolk which is high in lipids (fat), Egg white contains almost no fat, and carbohydrate content is less than $1 \%$. Egg white contains about $56 \%$ of the protein in the egg. Egg white has many uses in food and also many other uses (e.g in the preparation of some vaccines like influenza).

Egg white are susceptible to Salmonella contamination.

Egg white is a fining agent that can be used in the clarification and stabilization of wine. Egg white can also be added to shaken cocktails to create a delicate froth. Some protein powders also use egg white as a primary source of protein.

\subsection{Wound healing}

Wound healing is a complex process in which the skin, and the tissue under it repairs themselves after injury (Nguyyen DT et al., 2009) [6].. In undamaged skin, the epidermis (surface layer] and dermis [deeper layer] form a protective barrier against the external environment.When this blockade is broken, a regulated progression of biochemical events is set into motion to repair the damage (Rieger S et al.,2015) [7]. This process is divided into phases : blood clotting [hemostasis] , inflammation, tissue growth [proliferation], and tissue remodeling [maturation]. The wound healing process is not only complex but also fragile, and it is disposed to disruption leading to the formation of non-healing chronic wound. Factors that contribute to non-healing chronic wounds are diabetes, venous or arterial disease, infections, and metabolic deficiencies of old age (Enoch et al., 2004) [8]..

Wound care encourages and enhances wound healing by keeping the wound site clean and safe from reinjury or infection.

\subsection{Description of burn}

A burn is a type of injury to the skin or other tissues, caused by heat, cold, electricity, chemicals, friction or radiation (Herndon, 2012) [9]. Majority of burns are due to heat from hot liquids, solid or fire. While rates are same for both genders, the underlying causes often differ. Among women in some areas, risk is related to use of open cooking fires or unsafe cooking stoves. Among men, risk is related to the work environments. Alcoholism and smoking are other risk factors. Burns can occur as a result of self-harm or violence between people. Burns are generally preventable. Treatment depends on the severity of the burn.

\subsection{Epidemiology}

Although the alertness level of persons is escalating nowadays and preventive technologies are developed, burn is still one of the important causes of mortality and high morbidity. It is noted that more than 6million people are exposed to burns every year in the world, and that the mortality rate due to burns is 6-7\%. As the total body surface area affected by burn increases, the mortality rate also increases. Burns are most commonly seen in the upper and lower extremities. Burn traumas often result from an accident or neglect (Pham TN et al.,2008) [10].

\subsection{Etiology of burns}

Atleast $44^{\circ} \mathrm{Cof}$ heat is required for the skin to be burned. Besides, the length of the heat is also important; transepidermal necrosis occurring with $70^{\circ} \mathrm{C}$ of heat in a second, occurs in 45 minutes with $47^{\circ} \mathrm{C}$ of heat (Keck M. et al., 2009) [11].

Burns can be grouped according to thermal, chemical, electricity, and radiation (Ramponi DR. etal., 2017) [12]. The main cause of the burn should be known before commencement of treatment since a different treatment protocol is applied in each case. The time interval of the contact and the degree of the temperature determine the degree of cell damage. Other than these, burns can also develop due to electrical current, radiation, ultraviolet, and laser rays(Keck M. et al., 2009) [11].

\subsection{Types of burns}


THERMAL BURNS: This type of burn can occur either as hot water or as flame burns. Thermal burns are skin injuries caused by too much heat, typically from contact with hot surfaces, hot liquids, steam or flame. Thermal damage to skin results in cellular death. Thermal burns are the most common type of burn injuries. These burns are usually first-degree or superficial second-degree burns (Yin S, 2017) [13].

CHEMICAL BURNS: This type of burn is caused by cleaning materials that are used in daily life at home or by work accidents (Foris LA., et al 2017) [14]. Generally, it occurs due to contact with strong acid or alkaline substances. Unlike thermal burns, there is longer contact with the agent (Ramponi DR et al., 2017) [12].

ELECTRICAL BURNS: This type of burn occurs by electrical current or lightening strike. Low-voltage electrical burns are said to be less than 1000 volts and high-voltage electrical burns are saidto be more than 1000 volts; electrical burns between 250 and 1000 volts should be followed up just like high-voltage electrical burns since this patient may develop unconsciousness, compartment syndrome, and myoglobinuria/hemoglobinuria (Foris LA et al., 2017) [14].

RADIATION BURNS: This is caused by the uptake of radioactive material. The local radiation burns caused by high radiation doses (8-10 Gy) are similar to thermal burns except for several days to weeks of delayed latency. Taking high doses causes sudden cell death.

SUN BURNS: This develops due to uncontrolled or prolonged exposure to sun or light sources containing UVB. Sunburn is the contact dermatitis due to ultraviolet B rays (Freedberg IM et al.,1505-1513) [15].

COLD BURN (FROSTBITE): It is developed with cooling of the body. The skin is frozen at -2 to $-10^{\circ} \mathrm{Cand}$ irreversible changes occur under $-22^{\circ} \mathrm{C}$. Cold burn is different from thermal burns; trauma occurs at the cellular level and extracellular fluid directly, at the organ functions indirectly (Nizamoglu M etal., 2016) [16]. Electrolyte concentration increases with development of ice crystals in the intracellular and extracellular fluid, enzyme systems do not work and tissue destruction begins(Keck M et al., 2009) [11].

\subsection{Pathophysiology}

When burns occur, cell proteins in the skin denature and coagulate and thrombosis develops in vessels. Vascular permeability increases and denatured cell particles increase intracellular osmotic pressure.Vasoactive amines such as histamine, kinin, prostaglandin and serotonin are released from the burn developing tissue. Platelet and leucocyte adhesion to endothelium occurs. The complement system is activated cytotoxic T cells increase, and the tissue develops into an open site for infection.

\subsection{Symptoms of burn}

The symptoms of burns depends on the cause and type of burn. They can include:

- $\quad$ Blisters

- Pain (the degree of pain is not related to the severity of the burn,as the most serious burns can be painlesss.)

- Peeling skin

- Red skin

- Shock (symptoms of shock may include pale and clammy skin,weakness,bluish lips and fingernails,and a drop in alertness.)

- Swelling

- White or charred skin

\subsection{Burn levels}

We have three main types of burn; First, Second- and Third-degree burn. Each degree of burnis based on the severity of damage to the skin, with first degree being the most minor and the third degree being the most severe. Damage includes:

- $\quad$ First degree burns: red, on blistered skin

- Second degree burns: blister and some thickening of the skin

- Third degree burns: widespread thickness with a white, leathery appearance. 
There are also fourth-degree burns. These types of burn include all of the symptoms of third-degree burn and also extends beyond the skin into tendons and bones.

\subsection{Process Of Wound Healing}

There are four different phases that are involved in wound healing: hemostasis, inflammation, proliferation, and tissue remodeling or resolution (Gosain and DiPietro, 2004) [17]. These different phases and their biophysiological functions that are included must occur in the proper sequence, at a specific time, and continue for a specific duration at an optimal intensity (Mathieu et al., 2006) [18].

\section{Objectives/aim of the study}

The main aim/objective of the study is to screen the burn wound healing activity of a herbal preparation containing the Ethanol extract of Vernonia amydalina leaves, palm oil and egg albumin on burn wound inflicted Guinea pig.

\subsection{Justification Of Study}

Vernonia amygdalina is an affordable source of natural drug for wound healing. Elaeis guineensis has very cheap cost of production and dried egg albumen is easily available. When developed in a format it will be always affordable.

\section{Material and methods}

\subsection{Materials}

\subsubsection{Apparatus/equipments}

Test tubes, Beakers, Conical flasks, Measuring cylinders, Funnels, Filter pape r(Whatman No. 1), Spatula, Laboratory Water bath, Weighing balance, Rotary evaporator, Micrometer screw guage, Crucible, Microscope, Clean glass slide, Cover slip, Indelible marker, Syringes., Separating funnel, Retort stand, Hot-air oven (gallenkamp, UK), Stirrer (Glass rod), Petri dishes, Rack, Bunsen burner.

\subsubsection{Reagents}

Mayers reagent, dilute and conc. HCL, Dragendoff reagent, Ferric chloride solution,Molish reagent, Wagners reagent, Fehling's solution ( A\&B), Ruthenium red, Iodine solution, Phloroglucinol, Million's reagent, conc. Sulphuric acid, Picric acid solution, Dilute ammonium solution, Lead acetate solution, Ethyl acetate, Chloroform, diluted Phenol, Distilled water.

\subsubsection{Chemicals, solvents and drugs}

Ethanol, Methanol, Chloroform, Silica gel, Normal saline, Ketamine, Silver sulfadiazine cream ( Dermazin) 300mg/

\subsubsection{Animals}

Adult male guinea pigs weighing (500 - 600) gwere obtained from animal farm in Umuokpu village, Awka, Anambra State, and were housed in cages in the animal house of Madonna University Elele campus, Rivers state. Animals were maintained on standard pellets, Pennisetum purpureum (Elephant grass) and water.

\subsection{Methods}

\subsubsection{Plant collection and preparation}

Fresh leaves of $V$. amygdalina was identified and collected in the month of May, 2019 from department of pharmacognosy botanical garden, Madonna University Elele, Rivers State. Fresh palm oil (Elaeis guineensis) and fresh chicken eggs were purchased from Monastery market at pilgrimage centre Elele, Rivers state. The plant sample was authenticated for its botanical identity in the pharmacognosy herbarium of Madonna University. The fresh leaves were cleaned thoroughly and dried under room temperature for 2 weeks. The dried leaves were pulverized into powder and stored in an airtight container prior to extraction. 


\subsubsection{Extraction}

A quantity of $1000 \mathrm{~g}$ of sample was weighed and extracted by maceration using ethanol for 72 hours. The extract was then filtered using a Whatman filter paper and the extracted filterate was concentrated using a rotary evaporator at $36^{\circ}$ Cand dried completely in a water bath.

\subsubsection{Determination of extractive yield}

A clean dish was weighed and recorded, $1 \mathrm{ml}$ of the extract was introduced into the evapourating dish and evapourated in a hot air oven, it was allowed to cool and the weight was recorded. The weight of only the dish was subtracted with that of dish with residue. This process was repeated in duplicates and the value calculated from the average. The extractive value was calculated using the relation.

Yield $(\%)=$ Weight of extract $(\mathrm{g}) /$ Weight $(\mathrm{g})$ of plant material $\times 100$

\subsubsection{Macroscopic and organoleptic evaluation of leaf}

Using naked eyes and special senses (eyes, nose, tongue e.t.c.) the morphological characters of the leaf was examined. The following macroscopic/organoleptic characteristics were noted as follows; Texture, Odour, colour ,shape, apex ,taste, margin, petiole

\subsection{Microscopy of the leaf}

\subsubsection{Diagnostic epidermal characters of the leaf}

The epidermal membraneous layer of the leaf were carefully cut out into a transverse section and mounted on a clean slide with diluted glycerine after cleaning with chloral hydrate. The leaf fragment was covered with clean coverslip and observed under the microscope. The following characters were observed;

- Epidermal cells (nature)

- Stomata (type and distribution)

- Epidermal trichomes ( type and distribution)

- Cell inclusion (calcium oxalate crystal) (Trease and Evans, 1985) [17].

\subsection{Microscopy of the powdered leaf samples}

The powdered leaf was mounted on slips and viewed under microscope after being cleared with chloral hydrate.

\subsection{Chemomicroscopy of the leaf powder}

Test for Lignin: The powdered leaf was mounted on a few drops of phloroglucinol and concentrated $\mathrm{HCl}$ and observed under the microscope for a pink color.

Test for Starch: The powdered leaf was mounted in iodine solution and observed for a blue black coloration.

Test for Mucilage: Few drops of ruthenium red were added to the powdered leaf sample and the color change was observed. A pink color change is a positive test.

Test for Cellulose: The powdered leaf sample was mounted in iodine and $80 \% \mathrm{H}_{2} \mathrm{SO}_{4}$ and it was observed under the microscope for a blue black colour. The colour change is a positive test.

The powdered leaf sample and also the extract of Vernonia amygdalina was screened for their phytochemical components. The tests were carried out according to the procedures and methods outlined by Harbourne (1973) [19]. and Trease and Evans (2008) [20].

\subsection{Animal preparation}

Five (5) adult male Guinea pigs weighing between 500 - 600gwere used for this experiment. The animals were purchased from an Animal farm in Umuokpu Village Awka, Anambra State. They were housed in ventilated cages in the Animal house in Madonna University elele Campus. They were allowed to acclimatize for a period of two (2) weeks before carrying out the experiment. Saw dusts were used as beddings and the beddings were changed twice a week and once a week as the case may be throughout the period of acclimatization and thrice a week during the experiment. They 
were fed twice daily with pelletized growers mash mixed with starters mash, elephant grass, vegetable and water mixed with vitamin supplement. The feed was bought from Onitcha Main Market, Anambra State.

\subsection{Preparation of the drug}

The extract $10 \mathrm{mg}$, egg albumin $1.5 \mathrm{~g}$ and $20 \mathrm{mls}$ of Elaeis guineensis oil were robbed in a lab morter to a homogenous mixture which formed an emulsion. The product is stored in a $30 \mathrm{ml}$ volume bottle.

This procedure is repeated for the other concentrations $15 \mathrm{mg}, 20 \mathrm{mg}$ extracts, and stored at room temperature for the wound healing screening.

\subsection{Wound creation}

The burn injury was created on the dorsolateral region of the animals, after shaving the hairs using a pair of scissors, the animals were anaesthetized with $2 \mathrm{ml}$ of ketamine local anaesthesia around the region of the skin where the wound is to be inflicted, using a very hurt knife, a portion of the skin was burnt, creating a full thickness wound measuring approximately $400 \mathrm{~mm}^{2}$. Then the animals were randomly selected into five subjects for treatment according tothe drug concentrations prepared and the controls as shown below.

Subject A - Received from the mixture of $10 \mathrm{~g}$ extract of V.amygdalina, $20 \mathrm{mls}$ of the oil and $1.5 \mathrm{~g}$ of dried egg albumin(low concentration)

SubjectB - Received from the mixture of 15gextract of $V$. amygdalina, 20mls of the oil and $1.5 \mathrm{~g}$ of driedegg albumin (moderate concentration)

Subject C - Received from the mixture of $20 \mathrm{~g}$ extract of V.amygdalina, 20mls of the oil and $1.5 \mathrm{~g}$ of dried egg albumin(high concentration)

SubjectD - Control group and received just normal saline (negative control)

SubjectE - Received Silver sulfadiazine (Dermazin cream) (positive control)

\subsection{Drug administration/wound management}

The working solution for the wound treatment was prepared at three different concentrations of $10 \mathrm{~g}$ (low concentration), 15g (moderate concentration) and 20g (high concentration) for subjects $\mathrm{a}, \mathrm{b}$ and c respectively. This was done by thorough mixing $10 \mathrm{~g}, 15 \mathrm{~g}$ and $20 \mathrm{~g}$ extract respectively with $20 \mathrm{ml}$ of the bleached oil and $1.5 \mathrm{~g}$ of egg albumin using mortar and pestle for about 50mins so as to get a smooth homogenous mixture. The solution was then transferred in an air tight plastic container and stored in room temperature to ensure the potency is maintained.

\subsection{0. wound dressing}

The wounds were dressed immediately after the wound was inflicted. Dressing every other day continued throughout the period of the experiment which lasted for twenty-one (21) days. Normal saline was used to rinse the wound of debris then the mixture was applied topically on the wound. The wound surface is kept oily. The wound was covered with guaze and held firmly with plaster.

\subsection{Wound surface area / percentage rate of contraction}

The wound surface was calculated by multiplying the cross diameter of the wound on daily basis, while the percentage rate of contraction was calculated. 


\section{Results and discussion}

Extractive yield $=11.7 \%$

Table 1 Macroscopical characters

\begin{tabular}{|l|l|}
\hline Whole leaf & \\
\hline \multicolumn{1}{|c|}{ Character } & \multicolumn{1}{|c|}{ Description } \\
\hline Shape & Elliptic \\
\hline Surface & Smooth \\
\hline Venation & Reticulate \\
\hline Petiole & 6mm in diameter \\
\hline Apex & Acuminate \\
\hline Margin & Irregular serrate \\
\hline Base & Symmetrical \\
\hline Texture & Thin papery (dry) \\
\hline Colour & Green \\
\hline Odour & Characteristics \\
\hline
\end{tabular}

\subsection{Microscopical results}

Surface view showed almost straight walled epidermal cells on both surfaces. Upper surface has few anomocytic stomata.

The lower surfaces have numerous anomocytic stomata with smaller epidermal cells. Epidermal cells with straight anti clomal walls line both surface and contain single mucilage, layered palisade cells interrupted in mid rib region by collenchymatous cells, spongy mesophyll occupies the rest bundle of lamina space except for vascular bundle in veins and veinlets.

Microscopy of the powdered leaf shows anomocytic stomata with lignified xylem elements.

\subsection{Phytochemical test results}

\subsubsection{Test for carbohydrate}

Table 2 Molish test

\begin{tabular}{|l|l|l|}
\hline \multicolumn{1}{|c|}{ Test } & \multicolumn{1}{|c|}{ Observation } & \multicolumn{1}{|c|}{ Inference } \\
\hline $\begin{array}{l}\text { 2mls of aqueous extract+ 2 drops of } 10 \% \text { alcoholic solution of } \\
\text { naptholin, Tube was inclined at angle 45\% and 2mls of } \\
\text { concentrated H2S04carefully poured down the sides of the tube. }\end{array}$ & $\begin{array}{l}\text { Deep violet ring formed at } \\
\text { the interface of the two } \\
\text { layers. }\end{array}$ & $\begin{array}{l}\text { Carbohydrate is } \\
\text { present. }\end{array}$ \\
\hline
\end{tabular}

Table 3 Fehlings test

\begin{tabular}{|l|l|l|}
\hline \multicolumn{1}{|c|}{ Test } & \multicolumn{1}{|c|}{ Observation } & \multicolumn{1}{c|}{ Inference } \\
\hline $\begin{array}{l}\text { 2mls of fehling solution A + B was warmed with 2mls of } \\
\text { the aqueous extract. }\end{array}$ & $\begin{array}{l}\text { Brick red precipitate was } \\
\text { observed. }\end{array}$ & $\begin{array}{l}\text { Carbohydrate is } \\
\text { present. }\end{array}$ \\
\hline
\end{tabular}




\subsection{Test for cardiac glycosides}

Table 4 Keller-killiani test

\begin{tabular}{|c|c|c|}
\hline Test & \multicolumn{1}{|c|}{ Observation } & \multicolumn{1}{c|}{ Inference } \\
\hline $\begin{array}{l}\text { Aqueous extract }+2 \mathrm{mls} \text { of glacial acetic acid }+1 \\
\text { drop of ferric chloride solution }+1 \mathrm{ml} \text { of con H2SO4 }\end{array}$ & $\begin{array}{l}\text { A brown ring was observed at } \\
\text { the interface }\end{array}$ & Deoxy sugar present \\
\hline
\end{tabular}

Table 5 Kedde's test

\begin{tabular}{|l|l|c|}
\hline \multicolumn{1}{|c|}{ Test } & \multicolumn{1}{|c|}{ Observation } & Inference \\
\hline $\begin{array}{l}\text { 1ml of methanolic extract }+2 \% \text { of } 3,5 \\
\text { dinitrobenzoic acid in methanol }+1 \text { drop of } \\
\mathrm{NAOH}\end{array}$ & $\begin{array}{l}\text { Violet colour fading from reddish brown to } \\
\text { brownish yellow precipitate }\end{array}$ & Lactone ring present \\
\hline
\end{tabular}

Table 6 Test for for cyanogenetic glycosides

\begin{tabular}{|l|l|l|}
\hline \multicolumn{1}{|c|}{ Test } & \multicolumn{1}{|c|}{ Observation } & \multicolumn{1}{|c|}{ Inference } \\
\hline $\begin{array}{l}\text { 100mg of powdered drug was put in each of the 3 test tubes A,B } \\
\text { and C.little water was added to test tube A and B. sodium picrate } \\
\text { was put in each of the 3 test tube and stopped. }\end{array}$ & $\begin{array}{l}\text { Yellow colouration of } \\
\text { test papers retained. }\end{array}$ & $\begin{array}{l}\text { Cyanogenetic } \\
\text { glycoside absent }\end{array}$ \\
$\begin{array}{l}\text { Test tube B of the test plant was placed in boiling water for about } \\
\text { 5mins. Test tube A and C were kept at room temperature. }\end{array}$ & \\
\hline
\end{tabular}

Table 7 Test for saponins

\begin{tabular}{|c|c|c|}
\hline Test & Observation & Inference \\
\hline $5 \mathrm{mls}$ of aqueous extract $+5 \mathrm{mls}$ of water + vigorous shaking & $\begin{array}{l}\text { Persistent frothing } \\
\text { present }\end{array}$ & $\begin{array}{l}\text { Saponin } \\
\text { glycoside present }\end{array}$ \\
\hline $\begin{array}{l}5 \mathrm{mls} \text { of filterate }+5 \mathrm{mls} \text { of dilute } \mathrm{H} 2 \mathrm{SO} 4+\text { gentle boiling }+ \text { cool. The } \\
\text { residue was washed into a test tube with water + vigorous shaking. }\end{array}$ & $\begin{array}{l}\text { Persistent frothing } \\
\text { present }\end{array}$ & $\begin{array}{l}\text { Saponin } \\
\text { glycoside present }\end{array}$ \\
\hline $5 \mathrm{mls}$ of filterate + sodium bicarbonate + fehling solutioin & $\begin{array}{l}\text { Brownish Yellow } \\
\text { colouration present }\end{array}$ & $\begin{array}{l}\text { Saponin } \\
\text { glycoside present }\end{array}$ \\
\hline
\end{tabular}

\subsection{Test for tannins}

Table 8 General test

\begin{tabular}{|c|c|l|}
\hline Test & Observation & \multicolumn{1}{c|}{ Inference } \\
\hline $2 \mathrm{mls}$ of aqueous extract $+10 \mathrm{mls}$ of water +1 drop of FECL3 & Blue black precipitate & Tannin present \\
\hline
\end{tabular}

Table 9 Phenazone test

\begin{tabular}{|c|l|c|}
\hline Test & Observation & Inference \\
\hline $\begin{array}{l}\text { 500mg of sodium acid phosphate }+5 \mathrm{mls} \text { of drug extract }+ \\
\text { warmed, cooled and filtered filterate }+ \text { sufficient 2\% phenazone }\end{array}$ & $\begin{array}{l}\text { Reddish brown bulky } \\
\text { precipitate present }\end{array}$ & $\begin{array}{l}\text { True tannin } \\
\text { present }\end{array}$ \\
\hline
\end{tabular}


Table 10 Iron complex test

\begin{tabular}{|l|l|l|}
\hline \multicolumn{1}{|c|}{ Test } & \multicolumn{1}{|c|}{ Observation } & \multicolumn{1}{c|}{ Inference } \\
\hline $\begin{array}{l}5 \mathrm{mls} \text { of extract }+5 \mathrm{mls} \text { of } 0.25 \text { ferric ammonium } \\
\text { citrate }+1 \mathrm{~g} \text { of sodium acetate in a beaker }+ \text { boiled }+ \\
\text { cooled repeatedly }\end{array}$ & $\begin{array}{l}\text { A blackish bulky precipitate which } \\
\text { is insoluble in hot water }\end{array}$ & $\begin{array}{l}\text { Pseudo } \\
\text { present }\end{array}$ \\
\hline
\end{tabular}

Table 11 Formaldehyde test

\begin{tabular}{|l|l|l|}
\hline \multicolumn{1}{|c|}{ Test } & \multicolumn{1}{|c|}{ Observation } & \multicolumn{1}{c|}{ Inference } \\
\hline $\begin{array}{l}3 \text { drops of formaldehyde }+6 \text { drops of dilute HCL }+5 \mathrm{mls} \\
\text { of the extract }\end{array}$ & $\begin{array}{l}\text { A bulky precipitate which } \\
\text { leaves a coloured residue }\end{array}$ & Phloba tannin present \\
$\begin{array}{l}\text { Boiling and cooling were repeated to obtain precipitate } \\
+ \text { washed with hot water, warmed alcohol and warm 5\% }\end{array}$ & & \\
KOH & & \\
\hline
\end{tabular}

Table 12 Modified iron complex test

\begin{tabular}{|l|l|l|}
\hline \multicolumn{1}{|c|}{ Test } & \multicolumn{1}{|c|}{ Observation } & \multicolumn{1}{c|}{ Inference } \\
\hline 2mls of sodium potassium citrate +1 drop of 3.3\% acetic & Blackish precipitate & Hydrolysable tannin \\
acid +5 mls of aqueous extract + warmed precipitate was & which was insoluble in & obtained \\
filtered, washed and the washing added to the filtrate. & methanol, hot water or & \\
$0.25 \%$ ferric ammonium citrate was added until no further & dilute ammonium. & \\
intensification was obtained. It was then boiled. & & \\
\hline
\end{tabular}

Table 13 Test for flavonoids

\begin{tabular}{|l|l|l|}
\hline \multicolumn{1}{|c|}{ Test } & Observation & Inference \\
\hline $\begin{array}{l}\text { Dilute ammonium solution(5mls) }+2 \mathrm{mls} \text { aqueous } \\
\text { extract }+ \text { aqueous extract }+ \text { conc. } \mathrm{H} 2 \mathrm{SO} 4\end{array}$ & Yellow colouration present & Flavonoid present \\
\hline
\end{tabular}

\subsection{Test for alkaloids}

Table 14 Test for alkaloids Using polar solvent (water)

\begin{tabular}{|l|l|l|}
\hline \multicolumn{1}{|c|}{ Test } & \multicolumn{1}{c|}{ Observation } & \multicolumn{1}{c|}{ Inference } \\
\hline $\begin{array}{l}\text { 2mls of aqueous extract }+2 \mathrm{mls} \text { of Dragendroff } \\
\text { reagent }(\mathrm{DR})\end{array}$ & Orange precipitation present & Alkaloid salts absent \\
\hline $2 \mathrm{mls}$ of extract $+2 \mathrm{mls}$ of Wagner reagent $(\mathrm{WR})$ & Reddish brown precipitate present & Alkaloid salts absent \\
\hline $2 \mathrm{mls}$ of extract $+2 \mathrm{mls}$ of Harger reagent (HR) & Yellow precipitate present & Alkaloid salt present \\
\hline $2 \mathrm{mls}$ of extract $+2 \mathrm{mls}$ of Mayers reagent (MR) & Creamy precipitate present & Alkaloid salt present \\
\hline
\end{tabular}

Table 15 control (water)

\begin{tabular}{|l|l|l|}
\hline \multicolumn{1}{|c|}{ Test } & \multicolumn{1}{|c|}{ Observation } & \multicolumn{1}{c|}{ Inference } \\
\hline 2 mls of water $+2 \mathrm{mls}$ of $\mathrm{DR}$ & Light brown solution no precipitate & Alkaloids salts absent \\
\hline $2 \mathrm{mls}$ of water $+2 \mathrm{mls}$ of $\mathrm{WR}$ & Light brown solution no precipitate & Alkaloids salts absent \\
\hline $2 \mathrm{mls}$ of water $+2 \mathrm{mls}$ of HR & Yellow solution no precipitate & Alkaloids salts absent \\
\hline $2 \mathrm{mls}$ of water $+2 \mathrm{mls}$ of MR & Creamy solution no precipitate & Alkaloids salts absent \\
\hline
\end{tabular}


Table 16 Using polar solvent (10\% H2SO4)

\begin{tabular}{|l|l|l|}
\hline \multicolumn{1}{|c|}{ Test } & \multicolumn{1}{|c|}{ Observation } & \multicolumn{1}{c|}{ Inference } \\
\hline 2mls of water $+2 \mathrm{mls}$ of DR & Light brown precipitate present & Alkaloidal salts present \\
\hline 2mls of water $+2 \mathrm{mls}$ of $\mathrm{WR}$ & Light brown precipitate present & Alkaloidal salts present \\
\hline $2 \mathrm{mls}$ of water $+2 \mathrm{mls}$ of HR & Yellow precipitate present & Alkaloidal salts present \\
\hline $2 \mathrm{mls}$ of water $+2 \mathrm{mls}$ of MR & Creamy precipitate present & Alkaloidal salts present \\
\hline
\end{tabular}

Table 17 Using very polar solvent (methanol)

\begin{tabular}{|l|l|l|}
\hline \multicolumn{1}{|c|}{ Test } & \multicolumn{1}{|c|}{ Observation } & \multicolumn{1}{c|}{ Inference } \\
\hline $2 \mathrm{mls}$ of extract $+2 \mathrm{mls}$ of DR & Light brownish precipitate present & Alkaloidal salt and base present \\
\hline $2 \mathrm{mls}$ of extract $+2 \mathrm{mls}$ of $\mathrm{WR}$ & Brownish precipitate present & Alkaloidal salt and base present \\
\hline $2 \mathrm{mls}$ of extract $+2 \mathrm{mls}$ of HR & Yellowish green precipitate present & Alkaloidal salt and base present \\
\hline $2 \mathrm{mls}$ of extract $+2 \mathrm{mls}$ of WR & Creamy precipitate present & Alkaloidal salt and base present \\
\hline
\end{tabular}

Table 18 Using non polar solvent (chloroform)

\begin{tabular}{|l|l|l|}
\hline \multicolumn{1}{|c|}{ Test } & \multicolumn{1}{c|}{ Observation } & \multicolumn{1}{c|}{ Inference } \\
\hline $2 \mathrm{mls}$ of chloroform $+2 \mathrm{mls}$ of $\mathrm{DR}$ & Light brownish precipitate present & Alkaloidal base present \\
\hline $2 \mathrm{mls}$ of chloroform $+2 \mathrm{mls}$ of $\mathrm{WR}$ & Brownish precipitate present & Alkaloidal base present \\
\hline $2 \mathrm{mls}$ of chloroform $+2 \mathrm{mls}$ of HR & Yellowish green present & Alkaloidal base present \\
\hline $2 \mathrm{mls}$ of chloroform $+2 \mathrm{mls}$ of MR & Creamy precipitate present & Alkaloidal base present \\
\hline
\end{tabular}

Table 19 Results of the screening of wound healing effect of Elaeis guineensis OIL; extract of Vernonia amygdalina mixed with egg albumin on burn wound inflicted on guinea pig

\begin{tabular}{|c|c|c|c|c|c|}
\hline Subjects & $\begin{array}{l}\text { Agent used for } \\
\text { treatment }\end{array}$ & $\begin{array}{l}\text { Initial wound } \\
\text { area }\end{array}$ & $\begin{array}{l}\text { Wound area } \\
\text { after } 7 \text { days }\end{array}$ & $\begin{array}{l}\text { Wound area } \\
\text { after } 14 \text { days }\end{array}$ & $\begin{array}{l}\text { Wound area } \\
\text { after } 21 \text { days }\end{array}$ \\
\hline Subject A & $\begin{array}{l}\text { Low } \\
\text { concentration }(10 \mathrm{~g})\end{array}$ & $400 \mathrm{~mm}^{2}$ & $361 \mathrm{~mm}^{2}$ & $352 \mathrm{~mm}^{2}$ & $240 \mathrm{~mm}^{2}$ \\
\hline Subject B & $\begin{array}{c}\text { Medium } \\
\text { concentration }(15 \mathrm{~g})\end{array}$ & $400 \mathrm{~mm}^{2}$ & $169 \mathrm{~mm}^{2}$ & $120 \mathrm{~mm}^{2}$ & $70 \mathrm{~mm}^{2}$ \\
\hline Subject C & $\begin{array}{c}\text { High } \\
\text { concentration }(20 \mathrm{~g})\end{array}$ & $400 \mathrm{~mm}^{2}$ & $330 \mathrm{~mm}^{2}$ & $270 \mathrm{~mm}^{2}$ & $150 \mathrm{~mm}^{2}$ \\
\hline Subject D & Negative control & $400 \mathrm{~mm}^{2}$ & $430 \mathrm{~mm}^{2}$ & $352 \mathrm{~mm}^{2}$ & $324 \mathrm{~mm}^{2}$ \\
\hline Subject E & $\begin{array}{l}\text { Positive control( } \\
\text { dermazin } \\
\text { cream)300mg }\end{array}$ & $400 \mathrm{~mm}^{2}$ & $323 \mathrm{~mm}^{2}$ & $255 \mathrm{~mm}^{2}$ & $112 \mathrm{~mm}^{2}$ \\
\hline
\end{tabular}


Table 20 Pictures showing the rate of wound healing

\begin{tabular}{|c|c|c|c|c|c|}
\hline Subjects & $\begin{array}{l}\text { Agents used } \\
\text { for } \\
\text { treatement }\end{array}$ & Initial wound area & $\begin{array}{l}\text { Wound area } \\
\text { after } 7 \text { days }\end{array}$ & $\begin{array}{l}\text { Wound } \\
\text { area after } \\
14 \text { days }\end{array}$ & $\begin{array}{c}\text { Wound area after } \\
21 \text { days }\end{array}$ \\
\hline Subject A & $\begin{array}{l}\text { Low } \\
\text { concentration } \\
(10 \mathrm{~g})\end{array}$ & & & & \\
\hline Subject B & $\begin{array}{l}\text { Medium } \\
\text { concentration } \\
(15 \mathrm{~g})\end{array}$ & & & & \\
\hline Subject C & $\begin{array}{l}\text { High } \\
\text { concentration } \\
(20 \mathrm{~g})\end{array}$ & & & & \\
\hline Subject D & $\begin{array}{l}\text { Negative } \\
\text { control }\end{array}$ & & & & \\
\hline & Normal salin & & & & \\
\hline Subject E & $\begin{array}{l}\text { Positive } \\
\text { control } \\
\text { (dermazin } \\
\text { cream) 300mg }\end{array}$ & & & & \\
\hline
\end{tabular}

\section{Discussion}

The phytochemical analysis indicated the presence of glycosides (saponins), alkaloids Flavonoids, Phenols and Tannins holistically were responsible for the wound healing effects.

Elaeis guineensis Oil obtained from fruitmesocarp and palm kernel of E. guineensis are administered as poison antidote and can as well be used externally with several other herbs as lotion for skin diseases. The oil has antioxidant effects and a good source of vit. A. Tocotrienols from palm oil was potent inhibitors of lipid peroxidation and protein oxidation in rat brain mitochondrian. Kamat JP, Devasagayam TP [21].Vitamin E from palm oil is widely known as the major chainbreaking antioxidant and the first line of defense in protecting lipid membranes from peroxidation. The antioxidant properties of vitamin $\mathrm{E}$ are thought to be due to the fused heterocyclic ring. From the discussion palm oil has antioxidant and anti microbial properties. Palm oil provides a rich source of beta-carotene and vitamin E, namely tocopherols and tocotrienols which are recognized nutritional anti-oxidants that act as scavengers of the oxygen atom or free radicals. The palm oil is also used for biofuels and some manufactured products (Naher et al., 2013) [22]. Red palm oil is rich in 
natural phytonutrients that are important for health. These phytonutrients (i.e. tocotrienols and carotenes) are also powerful anti-oxidants which have wound healing effects in the body and help to maintain the stability of the oil during cooking process and may extend the shelf life of food prepared with red palm oil.

Research has shown that consumption of red palm oil significantly enhanced vitamin A levels in humans, and it is beneficial in preventing vitamin A deficiency (Manorama and Rukmini, (1991) [23]. and it is used for combating vitamin A deficiency in developing countries, additionally, some workers have advised that nursing mothers should take red palm oil as supplement with their food in order to prevent vitamin A deficiency (Lietz et al., 2000) [24]. Vitamin A deficiency may lead to blindness, skin disease and weakened immune function. The vitamin A content of the red palm oil plays important roles in growth, development and in visual process (Edem, 2009) [25(]. The human body is able to convert provitamin to carotenoids (alpha- and beta-carotene) when there is a deficiency, hence it is safer to supplement with carotenes than consuming vitamin A (retinoids) directly. In the body, vitamin E acts as an anti-oxidant that protects lipid from peroxidation and help quench free radicals.

The wound healing effect of palm oil is due to its content of Vitamin A and antioxidants.

Egg albumin has protein and vitamins which facilitated the wound healing. The egg albumin also supplied calcium and other factor essential in wound healing. In addition to having most of the egg's protein, it contains magnesium, riboflavin, potassium, sodium and niacin. Minerals such as zinc, phosphorus, copper and calcium are also found in egg albumin. These helps strengthen fingernails, bones and teeth. In addition, the egg albumin is rich in vitamins B6, B12 and D. The major protein present in egg albumen is known as "Ovalbumin" and it is the only protein of egg albumen that contains free SH groups. It also contains inhibitory peptides, antimicrobial peptides, and antioxidant peptides (LiChan and Kim, 2008) [26].

Vernonia. amygdalina has been demonstrated to have antioxidant, anti-inflammatory, anthelmintic, antidiarrheal, antihypertensive, and antidiabetic activities. The sap from the leaf has been used to treat pneumonia, bronchitis, and other respiratory diseases (Farombi and Owoeye, 2011 [27]; Ijeh and Ejike, 2011 [28]; Namukobe et al., 2011) [29]. The antioxidant substances in the extract played the wound healing role as well as anticancer surpressant.

All the three substances in the experimental drug, individually has some wound healing potentials hence the combination exhibited a very high level of therapeutic effect on wounds in the study.

The wound healing in the medium concentration was quick and the surface was rough. This shows that the concentration is high which gave the very abrupt healing but rough surface.

More work could be done on this to correct the concentrations in such a manner to produce smooth surface healing.

\section{Conclusion}

In conclusion, the most fascinating result of this work is the significant rapid wound size reduction and epithelization of wounds of the guinea pigs treated with the medium concentration of the extract $(15 \mathrm{~g}$ ) and positive control (dermazin) respectively. Although the guinea pig treated with the medium concentration healed faster than that treated with Dermazin, the one treated with dermazin cream is observed to heal very neatly when compared to the medium concentration. The study has shown that the mixture of the ethanol extract of the leaf Vernonia amygdalina, dried egg albumin and bleached palm oil possesses wound healing effect and can heal all degrees of burn wound.

\section{Compliance with ethical standards}

\section{Acknowledgments}

I acknowledge Laboratory Technologist in Pharmacognosy Department, faculty of pharmacy, Madonna University Nigeria, Mr. B Uwakwe who cared for the experimental animals.

\section{Disclosure of conflict of interest}

There is no conflict of interest among the authors. 


\section{Statement of ethical approval}

The protocol of this study was approved by the Faculty of Pharmacy Ethical committee Madonna University, Nigeria

\section{References}

[1] Saad, Bashar, Said, Omar. Greco-Arab and Islamic Herbal Medicine: Traditional System Ethics,, Safety, Efficacy, and Regulatory Issues. 2011.

[2] Odinsson, Eoghan. Northern Lore: A Field Guide to the Northern Mind-Body-Spirit. 2010.

[3] Talalay P, Talalay P. "The importance of using scientific principles in the development of medicinal agents from plants". Academic Medicine. 2001.

[4] Elvin-Lewis M. "Should we be concerned about herbal remedies". Journal of Ethnopharmacology. 2001.

[5] Izerbigie EB, Bryant JL, Walker A.A natural inhibitor of extracellular signals regulated kinensis and human breast cancer. 2004.

[6] Nguyen DT, Orgill DP, Murphy GT. The pathophysiology Basis for Wound Healing and Cutaneous Regeneration. Biomaterials for Treating Skin Loss. Elsevier. Pp. Orgill DP, Bianco C (4th ed). 2009.

[7] Rieger S, Zhao H, Martin p, Abe K, Lisse TS. The role of nuclear hormone receptors in cutaneous wound repair. Cell Biochemistry and Function. 2015.

[8] Enoch S, Price P. Cellular, molecular and biochemical differences in the pathophysiology of healing between acute wounds, chronic wounds and wounds in the elderly. 2004.

[9] Herndon D ed. Chapter 4: Prevention of Burn Injuries. Total burn care . Edinburgh: Saunders.(4th ed.). 2012.

[10] Pham TN, Cancio LC, Gibran NS. American burn association practice guidelines burn shock resuscitation. Journal of Burn Care \& Research. 2008.

[11] Keck M, Herndon DH, Kamolz LP, Frey M, Jeschke MG.Pathophysiology of burns. Wiener Medizinische. 2009.

[12] Ramponi DR. Chemical burns of the eye. Advanced Emergency Nursing Journal.2017.

[13] Yin S. Chemical and common burns in children. Clinical Pediatrics. 2017.

[14] Foris LA, Huecker MR. Electrical Injuries. Statpearls . Treasure Island StatPearls Publishing. 2017.

[15] Freedberg IM, Eisen AZ, Wolf K, Austen KF, Goldsmith L, Katz S, Fitzpatrick TB. Book: Dermatology in General Medicine). 1505-1513.

[16] Nizamoglu M, Tan A, Vickers T, Segaren N, barnes D, Dziewulski P. The 11-year experience of a tertiary burns centre. Burns \& Trauma. UK. 2016.

[17] Gosain A, DiPietro LA. Aging and wound healing, World J Surg.2004; 321-326.

[18] Mathieu JE, Schulze W. The influence of team knowledge and formal plans on episodic team process-performance relationships. Academy of Management Journal. 2006; 49:605-619.

[19] Harbourne J. Phytochemical methods. A Guide to Modern Techniques of Analysis. Chapman and Hall, London. 1973; 279.

[20] TreaseGI, Evans WC. Pharmacognosy, 15th ed. E.B Saunders, Edinburgh. London. 2008; 3-56.

[21] Kamat JP, Devasagayam TP. Tocotrienols from palm oil as potent inhibitors of lipid peroxidation and protein oxidation in rat brain mitochondria. Neurosci Lett. 1995;195:179-182.

[22] Naher L, Ho C-L, Tan SG, Yusuf UK, Abdullah F. Cloning of transcripts encoding chitinases from Elaeis guineensis Jacq. and their expression profiles in response to fungal infections. Physiol Mol Plant Pathol. 2011;76(2):96-103.

[23] Manorama R, Rukmini C. Nutritional evaluation of crude palm oil in rats. Am J Clin Nutr. 1991;53(4 Suppl):1031S$3 \mathrm{~S}$.

[24] Lietz et al. Red palm oil in the matanal improves the vitamin A status of lactating mothers and their infants June 2000 Food and Nutrition Bulletin. 2000; 21(2).

[25] Eunice CY Li-Chan, Hyun-Ock Kim. book: Biochemistry of foodspp 222 Google Books Result. 2008. 
[26] Edem BB. Assessment of Arithmetic learnind disability among Junior secondary school One students in Calabar Town, Nigeria. Unpublished M.Ed. Thesis. University of Calabar. 2009.

[27] Farombi EO, Owoeye 0. Antioxidative and Chemopreventive Properties of Vernonia amygdalina and Garcinia biflavonoid. International Journal of Environmental Research and Public Health. 2011; 8: 2533-2555.

[28] jeh II, Ejike CECC. Current Perspectives on the Medicinal Potentials of Vernonia amygdalina Del. Journal of Medicinal Plants Research. 2011; 5(7): 1051-1061.

[29] Namukobe J, Kasenene JM, Kiremire BT, Byamukama R, Mugisha MK, Krief S,Dumontet V, Kabasa JD. Traditional plants used for medicinal purposes by local communities around the Northern sector of Kibale National Park, Uganda. J. Ethnopharma. 2011; 136: 236-245. 